Limnological Review 10, 2: 77-85

DOI 10.2478/v10194-011-0009-1

\title{
Morphometry changes of Lake Ostrowskie (the Gniezno Lakeland) on the basis of cartographic, remote sensing and geodetic surveying
}

\author{
Mieczysław Kunz ${ }^{1}$, Rajmund Skowron ${ }^{2}$, Szymon Skowroński
}

Nicolaus Copernicus University in Toruń, Institute of Geography, ${ }^{1}$ Department of Cartography, Remote Sensing and GIS, ${ }^{2}$ Department of Hydrology and Water Management, Gagarina 9, 87-100 Toruń, Poland; e-mail: met@umk.pl, e-mail: rskowron@umk.pl

\begin{abstract}
The authors studied changes in the morphometry of Lake Ostrowskie over the period of 123 years on the grounds of cartographic materials, remote sensing data, land surveying, and data referring to the water stages. The changes that occurred in the lake up to the 1960s were related to the regulation and melioration works conducted in the entire area of the Gniezno Lakeland. On the other hand, drainage of the open pits of brown coal resulted in the considerable decline of the water table by another $2.5 \mathrm{~m}$ in the years 2002-2009. As a result of the decline of water down to $96.4 \mathrm{~m}$ a.s.l. the present lake was divided into two water bodies (the eastern one and the western one) joint with a channel. This led to the decline in the lake area from 346.7 ha in 1887 to 242.0 ha, and its volume by $28.9 \%$, out of which by $18.3 \%$ only in recent twenty-eight years.
\end{abstract}

Key words: lake, morphometry, temporal change, GPS, aerial photographs

\section{Introduction}

Lakes have evolved due to several stages of transformations, and at present they are at a different phase of the development of their basins. The evolution of the basins of postglacial lakes began when dead ice blocks had melted away, which in the case of most Polish lakes took place in the Alleröd, and more seldom in the Bölling. The pace of the transformations of the lake basin from the moment of its formation to the present times strongly fluctuated. Two major factors were of importance, namely: level changes (the decline) of lake waters and accumulation of biogenic and terrestric deposits in the basin. The lake basin has been systematically filled as a result of sedimentation and sedentation processes, which also leads to the further decline of the lake volume.

Another type of changes covers the recent 250 years, and is related to anthropogenic activity. This interference has resulted in considerable transformations, concentrated in a relatively short period of time. These changes are very noticeable when exploitation of minerals begins.

The Holocene record of the development of many lakes in Poland indicated that the water level at that time had varied and had been influenced by climatic factors most frequently (Lake Biskupińskie, Gościąż, Weneckie, Gąsawskie, Pakoskie, Gopło). These were long-term fluctuations which lasted for tens, hundreds and even thousands of years. On the other hand, the present fluctuations are of a shortterm character (seasonal, yearly or for some years only), and they tend to decline constantly. It is generally assumed that the average degree of the decline of the lakes related to the Weischelian glaciation is around $65-75 \%$, whereas, only in the years 1954-1992, the number of lakes decreased as much as by 2215 , ie. $11.2 \%$ of their area (Choiński 2007).

The "Dutch colonisation", which started to develop intensely from the end of the seventeenth century, brought about regulation of rivers and melioration of water-logged areas, concentrated mainly in the Noteć and Obra river valleys. The regulation works mainly involved drainage of water-logged areas, straightening river channels, canalization of many fragments of rivers and joining closed lakes into open systems. These works resulted in lowering of the water tables in many lakes of the Wielkopolska Lowland by $0.6-0.8 \mathrm{~m}$ on average, or in more extreme cases even by 1.1-1.4 m. Such a considerable interference brought about the 
decline of the lake area by several, or in more extreme cases by 80 percent (Kaniecki 1997). The lowering of the water table level also resulted in the decline of the lake volume. As Choiński (2001) points out the area of Lake Jamno decreased by approximately 150 ha over 70 years of the twentieth century, whereas its volume fell down by 9247 dam $^{3}$, ie. by $22.7 \%$.

Mineral exploitation conducted in Poland since the latter half of the eighteenth century caused considerable changes in the natural environment (Sawicki and Gutry-Korycka 1993). This is particularly noticeable with respect to brown coal open pits whose extraction requires drainage of the area surrounding a particular open pit. Deep depression sinks of various extent develop as a result of that drainage, depending upon the amount of pumped out water. One of the well-documented examples can be seen in the area of the Bełchatów brown coal mine, which is located in the catchment of the River Widawka, the right-side tributary of the River Warta (Wachowiak 2005). The areas of the "Konin" and "Pątnów" mines located in the catchment of the Warta-Gopło Channel, where several lakes (Gosławskie, Pątnowskie, Licheńskie, Mikorzyńskie and Ślesińskie) are located, can serve as other examples. The system of formation drainage in this area brought about forced water infiltration from Lake Gosławskie, causing a six-time bigger increase of water infiltration from Lake Gosławskie with concurrent lack of underground inflow to the lake (Pasławski 1968).

Another example of the influence of anthropopressure upon the water table can be seen in the transformations which have taken place in Lake Gopło in recent 238 years. Regulation works conducted in the Noteć river channel in the years 1775-1878 and melioration procedures in its upper section resulted in the decline of the water table in the lake by approximately 3.3 metres. The basin of the present lake covers only the deepest parts of the former water body, ie. merely $19.2 \%$ of the lake area observed before 1772 , and $28.1 \%$ of its former volume (Dorożyński and Skowron 2002).

This work shows the consequences of mine draining and its influence upon water relations in the lakes located in the eastern part of the Gniezno Lakeland. The water level in the lakes has considerably declined since 2002 as a result of the Konin Brown Coal Mine operation. In the years 2002-2005 the water table in the water bodies fell down dramatically even by 2 metres. Such changes result in the decline of their value of even 22.9\% (Marszelewski and Radomski 2008). This problem concerns six lakes: Budzisławskie, Powidzkie, Suszewskie, Wilczyńskie, Wójcińskie and Ostrowskie, located in the eastern part of the Gniezno Lakeland (Fig. 1).

Lake Ostrowskie and the catchment of the Ostrowo-Gopło Channel are located in the eastern part of the Gniezno Lakeland which belongs to the macro-region of the WIelkopolska Lakeland. It borders with the Chodziez Lakeland in the north, with the Poznan Lakeland in the west, with the channel of Lake Gopło in the east, and with the Wrzesińska Plain in the south.

Lake Ostrowskie was drained through the Ostrowo-Gopło Channel which in recent six years has become an episodic stream. The direct catchment of the lake amounts to $10.3 \mathrm{~km}^{3}$. Forests cover $67 \%$ of its area, farming lands $26.1 \%$, and grassland and other forms take approximately $6.9 \%$. Several streams flow into the lake, out of which the inflow from Lake Kownackie is a regular watercourse.

This study intends to determine what changes have taken place in Lake Ostrowskie through the analysis of morphometric properties of its basin on the grounds of the collected archival cartographic materials, remote sensing data, and direct surveying.

The application of cartographic and remote sensing methods in the examination of temporal changes of the shorelines can be found in several scientific works concerning both Polish and world water bodies. These works have accounted for panchromatic and colourful aerial photographs and satellite images (Serafin 2008; Aleskeikh et al. 2007; Rongxing et al. 2001).

\section{Materials and investigation methods}

The archival cartographic materials, remote sensing data and the results of land surveying with the use of GPS receiver were applied to the research (Table 1). The time span of the study is delimited by two stages - the oldest coming from the topographic map (the so-called Messtischblätter) at the scale 1:25000 made in 1887 (the sheet Gembitz published by Preuß. Landesaufnahme) and the latest coming from the detailed field exploration conducted in 2009 with the use of GPS surveying receiver.

Desk studies were connected to the construction of a complete geographic information system, whose fundamental information layers included the archival topographic maps and multitemporal aerial photographs. All the original materials were scanned and 


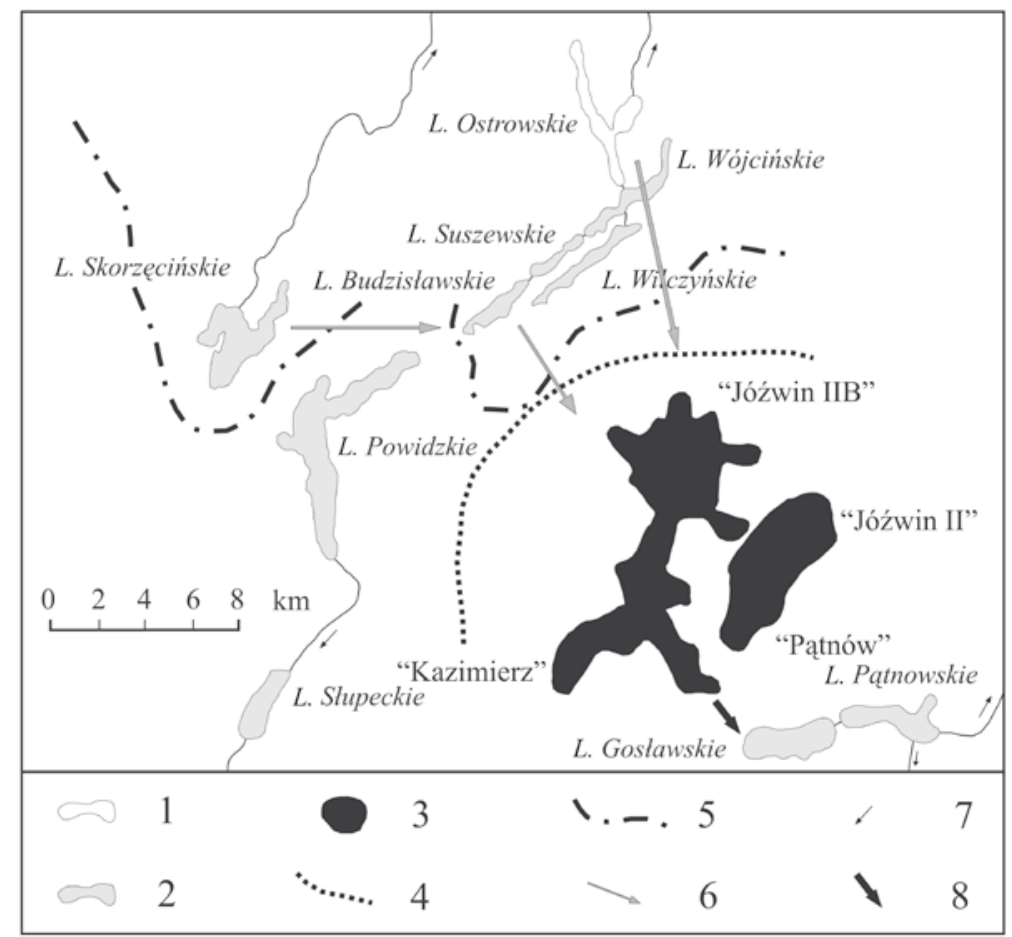

Fig. 1. Location of the lakes and the open pits of the Konin Brown Coal Mine: 1 - Lake Ostrowskie, 2 - other lakes, 3 - limits of the existing open pits, 4 - limit of the depression sink, 5 -watershed, 6 - directions of groundwater runoff, 7 - direction of the river outflow, 8 - direction of the water pumped out from the open pits (according to Orłowski and Ilnicki 2007)

Table 1. The list of used cartographic and remote sensing materials

\begin{tabular}{|l|l|r|r|}
\hline No. & \multicolumn{1}{|c|}{ Items } & Scale & Validity \\
\hline 1 & A German topographic map, sheet 1865 (Gembitz) & $1: 25000$ & 1887 \\
\hline 2 & A German topographic map, sheet 3474 (Gembitz) & $1: 25000$ & 1911 \\
\hline 3 & A bathymetric plan of the lake, Institute of Inland Fisheries & $1: 5000$ & 1960 \\
\hline 4 & A topographic map, the so-called "poviat map", Topographic Board SG WP & $1: 25000$ & 1964 \\
\hline 5 & Panchromatic aerial photographs, no data about the precise date of the flight & $1: 30000$ & 1980 \\
\hline 6 & Topographic maps: 364.441, 364.442, 364.443, 334.444, 374.222 & $1: 10000$ & 1981 \\
\hline 7 & Panchromatic aerial photographs, no data about the precise date of the flight & $1: 27000$ & 1991 \\
\hline 8 & Colourful aerial photographs taken on 11th August 1996 & $1: 26000$ & 1996 \\
\hline 9 & Panchromatic aerial photographs taken on 14th April 2004 & $1: 26000$ & 2004 \\
\hline 10 & Direct GPS measurements - Leica GPS GX 1230 taken on 19th February 2009 & n/a & 2009 \\
\hline
\end{tabular}

calibrated with the Polish National Coordinate System 1992. The calibration of all the aerial photographs and topographic maps was conducted in respect of situation details found in the topographic map at the scale 1:10 000, which was made in 1891. The calibration error of the applied scans of the topographic maps, plans and aerial photographs did not exceed the accuracy degree of their originals. This made it possible to obtain cartometric raster images, which in subsequent stages of work could be compared with one another. The source materials prepared in such a way allowed the authors to carry out vectorization of the shoreline of Lake Ostrowskie. In this way the authors established nine outlines of the shoreline from the following periods: 1887, 1911, 1960, 1964, 1980, 1981, 1991, 1996, and 2004. The determination of the boundary of the shoreline made it possible to define the entire area of the lake in the studied period. 
The present outline of the shoreline was obtained through the direct measurement carried out on 19 February 2009 with the use of GPS surveying receiver Leica - GX1230 GG. The terrain coordinates were established in the Real Time Kinematic monitoring mode, and corrections of the coordinates were obtained online from the ASG-EUPOS network. This enabled the authors to achieve accuracy of the measurement of the measured point location at the scale of approx. $0.020 \mathrm{~m}$ in the horizontal and $0.036 \mathrm{~m}$ in the vertical. Altogether, 1106 terrain points were measured, out of which 839 are located in the present western part of the water body, and 277 are found in the eastern one. While determining the ordinate of the water table for the GPS measurement, the up-to-date outlines of the shoreline and the lake area were obtained. That lake area is a reference level for all the previous results (Fig. 4).

The authors also accounted for the mean annual and monthly water stage indexes in the lake in the period 1993-2009. They were shown on the watergauge located in the eastern part of the water body. The calculations of the water volume changes were based upon the bathymetric plan of the lake made in the winter of 1960 by the Institute of Inland Fisheries in Olsztyn. The water table heights in various years (from 1887 to 2009) were determined on the grounds of the cartographic materials analyses and land surveying measurements.
The bathymetric plan became a starting point. The water stage and the lake volume were referenced to it, and moreover, the decrements or increments of water retention resources in particular years were either subtracted or added to it. A formula for the sum of cylinders was applied.

\section{Location and hydrological characteristics of the study area}

The studied area is located in the region of relatively low precipitation indexes. The mean annual sum of precipitation at the meteorological station in Gniezno recorded in the period 1951-2006 amounted to $514 \mathrm{~mm}$, and varied considerably in particular years. The biggest precipitation was recorded in 1967 (789 $\mathrm{mm})$, and $1961(731 \mathrm{~mm})$, whereas, the lowest precipitation values were observed in the years: 1982 (298 mm), $1959(340 \mathrm{~mm})$, and 1989 (342 mm). The course of the annual sums in the analysed period showed a positive trend at the level of $1.07 \mathrm{~mm} \cdot \mathrm{yr}^{-1}$, while in the years 1993-2006 there was a distinctively negative trend (Fig. 2).

The above climatic conditions influence the course of the mean annual and monthly water stages in the lake (Fig. 3). The measurements of water stages conducted in Lake Ostrowskie showed that in the years 1993-1998 the mean water level had remained at the level of $97.45 \mathrm{~m}$ a.s.l. and had been by approximately

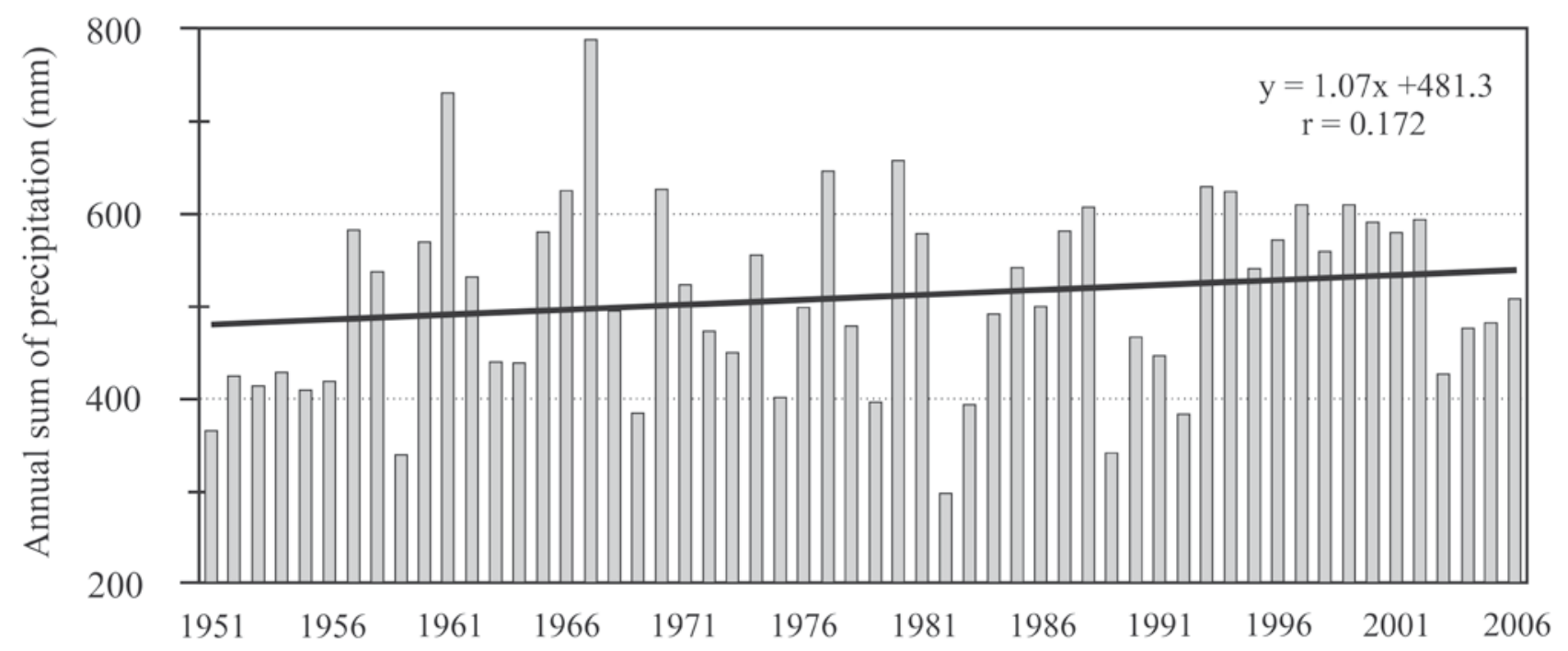

Fig. 2. The course of the annual sums of precipitation $(\mathrm{mm})$ at the meteorological station in Gniezno and the trend line in the years 1951-2006 (prepared on the grounds of the data obtained from the Institute of Meteorology and Water Management) 


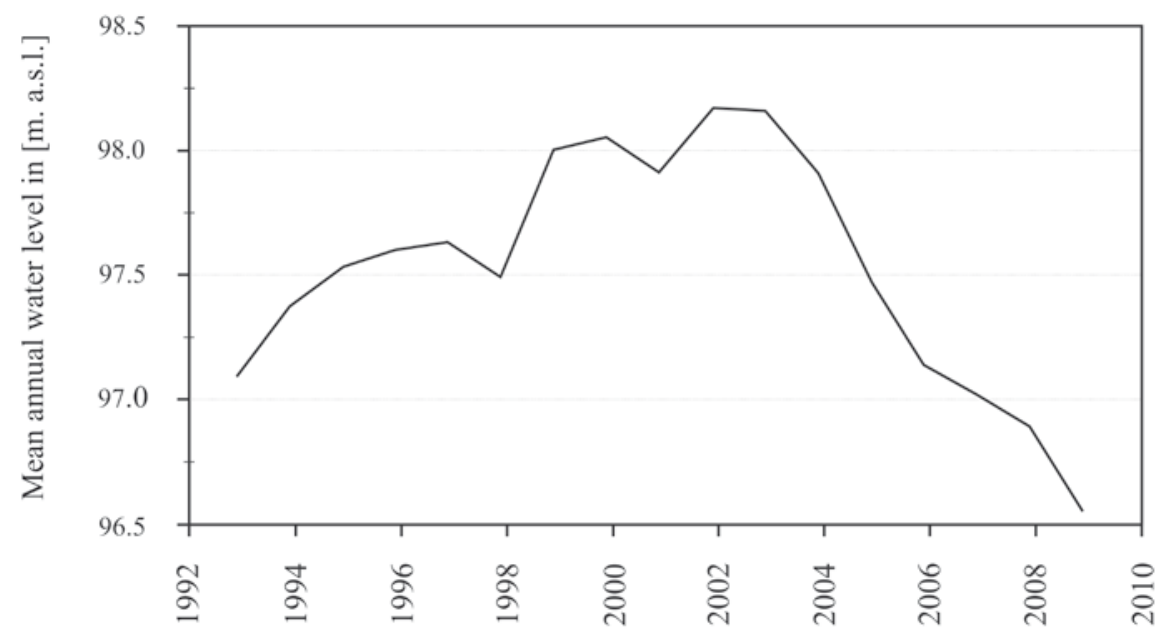

Fig. 3. The mean annual location of the water table in Lake Ostrowskie during the period 1993-2009 (prepared on the grounds of the data obtained from the Institute of Meteorology and Water Management)

1.3-1.5 m lower than the one in the 1969s. From 1999 the water level rose by $0.6 \mathrm{~m}$ (98.03 $\mathrm{m}$ a.s.l.), and after 2004 it declined again by 0.5-0.6 m (97.01 m a.s.l.). Particularly significant changes occurred in 2005 when the water level declined down to $96.55 \mathrm{~m}$ a.s.l. A passive hydrological character of Lake Ostrowskie mainly results from the low index of water exchange $(\alpha=0.29)$ to 2003 , and the small annual amplitude of water stages.

\section{Results and discussion}

Similarly to other lakes located in the area of the last glaciation, Lake Ostrowskie has undergone significant changes due to increasing anthropopressure.

The analyses of available cartographic materials and remote sensing data and surveying measurements confirm the investigations carried out by other authors (Niewiarowski 1978; Choiński 2001; Dorożyński and Skowron 2002; Marszelewski 2005), who conclude that the level of the water table in many Polish lakes has considerably declined for over 120-130 years. This also refers to the lakes located in the Gniezno Lakeland, including Lake Ostrowskie in particular.

As a result of regulation works conducted in the upper catchment of the Noteć River before 1887 the water level declined in Lake Ostrowskie and got stable at 99.0-100.0 $\mathrm{m}$ a.s.l. The lake's area determined on the grounds of the maps from 1887 amounted to 346.7 ha. A significantly lower area characterizes the lake in the map which was made in 1911 (313.5 ha). The water table in the lake remained at $99.0 \mathrm{~m}$ a.s.l. It should be remembered that after the catastrophic flood in the area of the upper Notec in the years 1854-1855 the water level in Lake Gopło was decreased by $1.4-1.5 \mathrm{~m}$ (78.3 $\mathrm{m}$ a.s.l.). At the same time the Ostrowo-Gopło Channel was dug to be used for local sailing purposes. The level of the water table in Lake Ostrowskie may have been at 99.5-100 $\mathrm{m}$ a.s.l., which guaranteed the outflow of waters to Lake Gopło and free sailing. However, there is no irrefutable evidence which could confirm functioning of the lake at such a level.

Another stage covers a relatively peaceful period and concerns the first half of the twentieth century (1911-1960). The bathymetric plan of the lake made by the Institute of Inland Fisheries in Olsztyn in February 1960 and the authors' other direct observations point to the minimal hydrological changes in the lake system.

Considerably bigger changes occurred as late as in the 1980s, and were brought about by low precipitation and melioration works conducted in the lower catchment of the Ostrowo-Gopło Channel at that time. The outflow from the lake declined significantly. The lake's water table gets lowered down to $98.5 \mathrm{~m}$ a.s.l., while its area decreases to 282.9 ha (32\%), and its volume amounts to $4.8 \%$. The shoreline also lengthens noticeably.

Bigger changes can be observed only after 1992 . At this time the lakes located in the southern part 

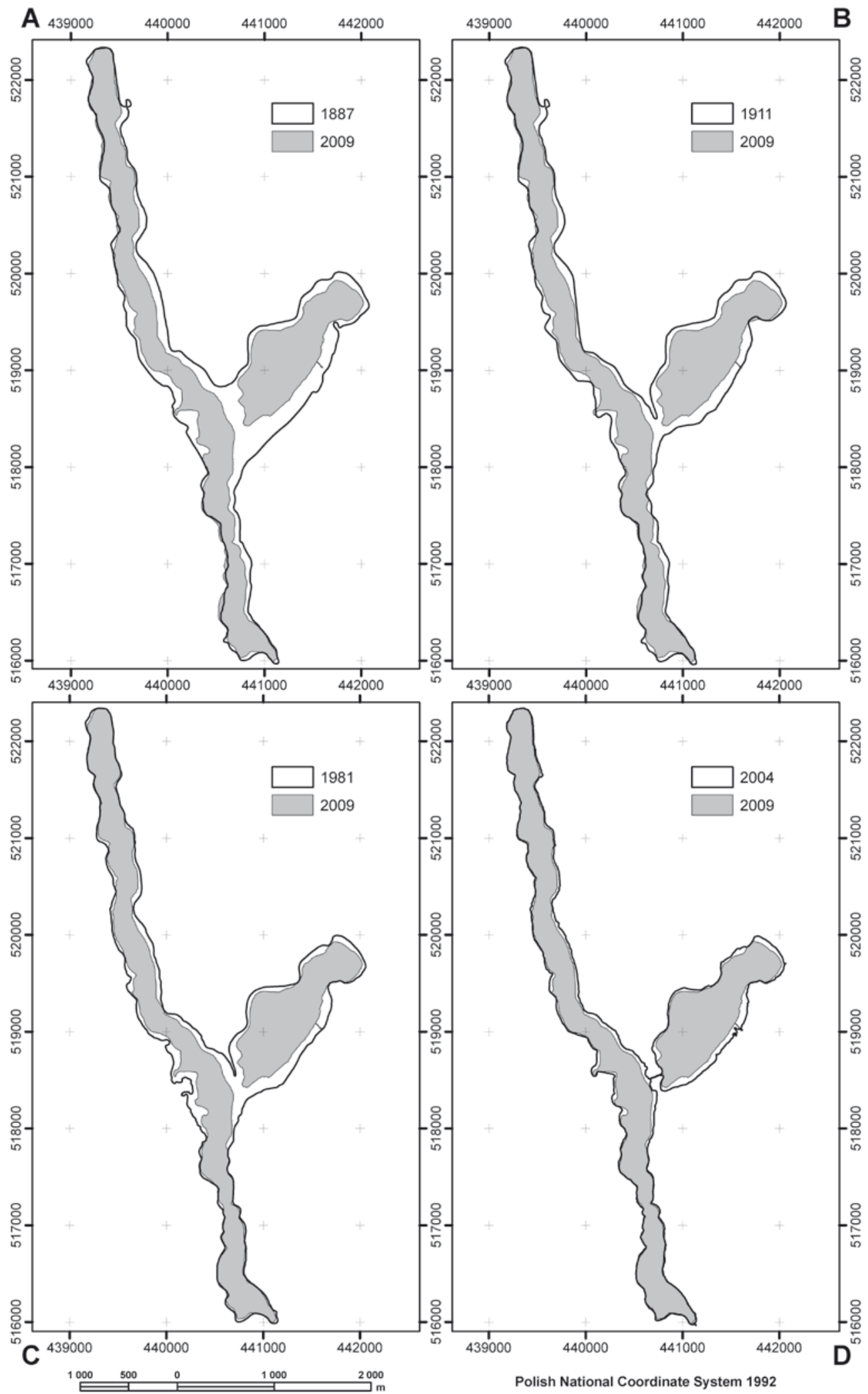

Fig. 4. The area of Lake Ostrowskie in 2009 on the background of: A - lake area in 1887, B - lake area in 1911, C - lake area in 1981, and $\mathrm{D}$ - lake area in 2004 
of the Gniezno Lakeland stayed within the range of the depression sink of the Konin Brown Coal Mine. The investigations carried out in the years 1995-2006 proved that all the lakes located in the depression sink showed that their water table levels declined as early as in the years 1992-1993 (Ilnicki 1996, Ilnicki and Orłowski 2006, Orłowski and Ilnicki 2007). Yet, violent decreases in water stages occurred after 2000 (Lake Suszewskie and Wilczyńskie), and in other lakes after 2003.

The data in Table 2 indicate unambiguously that the level of the water table in all the lakes located in the eastern part of the Gniezno Lakeland has gone down by $0.32-2.53 \mathrm{~m}$ for the last 28-30 years.

A considerable decline in the water level in all the lakes was observed in the years 2002-2005, when the mean water stage declined by $0.4 \mathrm{~m}$ in Lake Powidzkie, $0.8 \mathrm{~m}$ in Lake Budzisławskie, $1.0 \mathrm{~m}$ in Lake
Wilczyńskie, $1.5 \mathrm{~m}$ in Lake Wójcińskie and Lake Suszewskie, and by $1.4 \mathrm{~m}$ in Lake Ostrowskie. This resulted in the decrease of water resources in these lakes by 3.4-22.9\% (Marszelewski and Radomski 2008).

Changes in the lake's area and the elements referring to the form of the lake basin are the measurable consequences of the decline of the water level. The area of the water table in Lake Ostrowskie diminished by nearly 105 ha, ie. by $30.2 \%$, in the years $1887-2009$. The pace of that change varied, though (Table 3 ). Changes in the lake volume were of a similar character. The volume decreased by $28,9 \%$ in the years $1887-2009$, while as much as by $18.3 \%$ in the last 28 years.

The falling lake volume exposed new areas, particularly shallow-water ones, yet mainly it caused big changes in the selected sub-aquatic elements. The shoreline altered significantly, which could be seen in the selected periods as compared to its extent in 2009

Table 2. Changes in the water stages in the selected lakes located in the borderland between the Gniezno and Kujawy Lakelands in the years 1960-2005 (according to Orłowski and Ilnicki 2007, partially changed)

\begin{tabular}{|c|c|c|c|c|c|c|}
\hline \multirow{2}{*}{ Lake } & \multirow{2}{*}{ Area [ha] } & \multicolumn{4}{|c|}{$\begin{array}{c}\text { Mean annual water level in [m a.s.I.] } \\
\text { in a hydrological year }\end{array}$} & \multirow{2}{*}{$\begin{array}{l}\text { Water level decline in the } \\
\text { years } 1965-2005\end{array}$} \\
\hline & & 1965 & 1994 & 2000 & 2005 & \\
\hline Niedzięgiel & 602.5 & 104.00 & 103.10 & 03.49 & 103.12 & -0.88 \\
\hline Powidzkie & 1097.5 & 98.35 & 98.04 & 98.18 & 97.96 & -0.32 \\
\hline Budzisławskie & 157.5 & 99.40 & 98.41 & 98.60 & 97.83 & -1.57 \\
\hline Suszewskie & 205.0 & 99.20 & 97.89 & 97.78 & 96.67 & -2.53 \\
\hline Wilczyńskie & 87.5 & 99.00 & 97.71 & 98.08 & 96.69 & -2.31 \\
\hline Wójcińsko-Kownackie & 237.5 & 98.90 & 97.86 & 98.07 & 97.50 & -1.40 \\
\hline Ostrowskie & 315.0 & 98.90 & 97.37 & 98.05 & 97.47 & -1.43 \\
\hline Skulskie & 120.0 & 85.90 & 86.14 & 86.01 & 85.92 & +0.02 \\
\hline Gopło & 2121.5 & 76.82 & 76.89 & 76.69 & 76.59 & -0.23 \\
\hline
\end{tabular}

Table 3. Percentage share in the changes in the area and volume, and the pace of those changes in Lake Ostrowskie in the years 1887-2009

\begin{tabular}{|c|c|c|c|c|c|c|c|c|}
\hline \multirow[b]{2}{*}{ Year } & \multirow[b]{2}{*}{$\begin{array}{c}\text { Water table } \\
\text { index } \\
\text { [m a.s.l.] }\end{array}$} & \multicolumn{4}{|c|}{ Lake area } & \multicolumn{3}{|c|}{ Lake volume } \\
\hline & & in ha & $\begin{array}{l}\text { Change of } \\
\text { the area } \\
\text { in ha }\end{array}$ & $\begin{array}{l}\text { Percentage } \\
\text { of the change } \\
\text { in relation to } \\
\text { the previous } \\
\text { period }\end{array}$ & $\begin{array}{l}\text { Pace } \\
\text { of the } \\
\text { change in } \\
\text { ha·yr }\end{array}$ & in dam ${ }^{3}$ & $\begin{array}{l}\text { Percentage } \\
\text { of the change } \\
\text { in relation to } \\
\text { the previous } \\
\text { period }\end{array}$ & $\begin{array}{c}\text { Pace of the } \\
\text { change in } \\
\text { dam }^{3} \cdot \mathrm{yr}^{-1}\end{array}$ \\
\hline 1887 & 99.9 & 346.7 & & & & 34526.3 & & \\
\hline 1911 & 99.0 & 313.5 & -33.2 & -10.6 & -1.4 & 31555.4 & -8.6 & -123.8 \\
\hline 1960 & 98.9 & 314.5 & +1.0 & +0.3 & 0.0 & 31242.9 & -1.0 & -6.4 \\
\hline 1981 & 98.5 & 282.9 & -32.1 & -11.3 & -6.4 & 30057.1 & -4.8 & -56.5 \\
\hline 1996 & $97.37^{\mathrm{a}}$ & 270.0 & -12.9 & -4.6 & -0.9 & 26933.1 & -10.4 & -208.3 \\
\hline 2004 & $97.47^{\mathrm{a}}$ & 279.1 & +9.1 & +3.4 & +1.1 & 27207.7 & +0.9 & +34.3 \\
\hline 2009 & 96.4 & 242.0 & -37.1 & -15.3 & -7.4 & 24545.6 & -18.3 & -196.8 \\
\hline
\end{tabular}


(Fig. 4). At present Lake Ostrowskie is composed of two water bodies divided by a wide dyke, which was artificially dug to create a channel that is $70 \mathrm{~m}$ long and 2-3 $\mathrm{m}$ wide. The western part is of a narrow channel character (approx. $6.5 \mathrm{~km}$ long and up to $0.4 \mathrm{~km}$ wide) and has a series of consecutive kettle lakes. Whereas, the eastern one constitutes a large water body which is approximately $0.9 \mathrm{~km}$ wide and has a centric net of isobaths and a wide littoral zone (Fig. 3).

The character of the changes in the parameters referring to the sub-aquatic features of the lake basin (the mean depth, depth index, and the lake basin permanence index) are presented in Table 4. This is particularly noticeable while analyzing the parameters which describe the relationship between horizontal and vertical dimensions of the lake basin (a depth index $-c$, a relative depth index $-C_{R}$ ) (Skowron 2004).

\section{Conclusions}

The long-term exlploitation of brown coal in this region required lowering of waters in the Tertiary-Cretaceous layer by 60-70 m (the Pątnów open pit exploited in the years 1962-2001 reached the depth of $59 \mathrm{~m}$, Jóźwin IIB open pit exploited in the years 2004-2020 has the average depth of $70 \mathrm{~m}$ ). According to Orłowski and Ilnicki (2007), there may be hydraulic windows in the vicinity of Lake Suszewskie and Wilczyńskie, thanks to which there is runoff of surface waters to the lower levels.
The decline of waters in these lakes, which is an effect of forced infiltration (the lowest water level above the sea level), causes the inflow of the waters from other lakes into them. This is confirmed by the directions of surface waters outflow between those water bodies.

The increase of pumped out water in 2004 and 2005 caused an immediate consequence related to the decline of the water table in all the lakes of this region. The amount of water drained from the Jóźwin IIB open pit ranged from $14.41 \mathrm{hm}^{3}$ in 2000 to $26.84 \mathrm{hm}^{3}$ in 2005 (Ilnicki and Orłowski 2006). Mining water coming from drainage is directed to Lake Gosławskie and Lake Ślesińskie. In 2003 the 150-year outflow of waters from Lake Ostrowskie through the OstrowoGopło Channel to Lake Gopło, which is located $11 \mathrm{~km}$ away, stopped.

Exposure and destruction of the littoral zone, an important element in the food link of this ecosystem, appear the negative consequences of the water decline in Lake Ostrowskie. According to Ilnicki (1996), in order to improve and rescue this unfavourable hydrological situation in the above mentioned lakes, it is vital to direct the pumped out waters to Lake Budzisławskie and Skorzęcińskie.

The decision to direct the water pumped out from the Jóźwin IIB open pit into two lakes: Budzisławskie and Wilczyńskie through an eight-kilometre pipeline seems promising. In such a way partial realimentation of water relations can be undertaken. The costs are to

Table 4. Changes in morphometric parameters of Lake Ostrowskie in the years 1887-2009

\begin{tabular}{|c|c|c|c|c|c|c|c|c|c|c|c|}
\hline No. & Year & 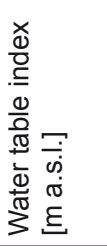 & 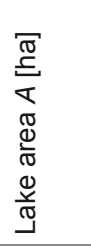 & 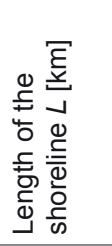 & 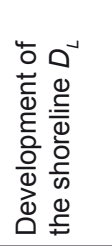 & 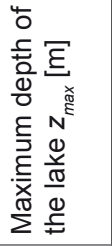 & 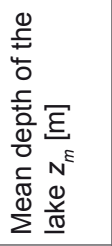 & 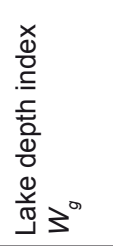 & 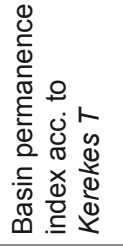 & 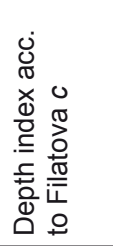 & 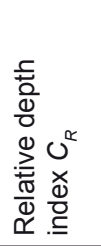 \\
\hline 1 & 1887 & 99.00 & 346.7 & 19.0 & 2.88 & 35.2 & 9.12 & 0.26 & 1.66 & 69.3 & 18.0 \\
\hline 2 & 1911 & 99.00 & 313.5 & 19.9 & 3.17 & 35.2 & 10.06 & 0.29 & 1.59 & 76.7 & 21.9 \\
\hline 3 & 1960 & 98.90 & 314.5 & 19.9 & 3.17 & 35.1 & 9.93 & 0.28 & 1.57 & 75.9 & 21.5 \\
\hline 5 & 1981 & 98.50 & 282.9 & 21.0 & 3.52 & 34.7 & 10.62 & 0.31 & 1.43 & 83.4 & 25.5 \\
\hline 7 & 1996 & $97.37^{a}$ & 270.0 & 20.5 & 3.52 & 33.6 & 9.98 & 0.30 & 1.31 & 84.6 & 25.1 \\
\hline 8 & 2005 & $97.47^{a}$ & 279.1 & 20.9 & 3.52 & 33.7 & 9.75 & 0.29 & 1.30 & 82.1 & 23.8 \\
\hline 9 & 2009 & 96.40 & 242.0 & 20.1 & 3.64 & 32.6 & 10.14 & 0.31 & 1.22 & 91.6 & 28.5 \\
\hline
\end{tabular}

Explanation: $D_{L}=L / 2 \sqrt{\pi P}, \quad W_{g}=z_{m} / Z_{\max }, \quad T=V / L, \quad c=\left(z_{\max } / B_{m}\right) \times 10^{-3}$ where $B_{m}$ is lake mean width in meters, $C_{R}=\left(Z_{m} / B_{m}\right) \times 10^{-3},{ }^{\text {a }}-$ the mean annual water level in the lake according to Orłowski and Ilnicki 2007 
be shared among the Voivodeship Fund for Environmental Protection, the Kujawsko-Pomorski Marshal's Office and the gminas interested in this problem.

The archival cartographic materials and remote sensing data are a very valuable information source of the lake's past, its condition and its properties. In the connection with modern spatial data processing methods they constitute an excellent base for comparative analyses, including studies of the changes in the morphometry of the lakes.

The ASG-EUPOS system launched on 2 June 2008 accounts for fast and very precise single measurements with the use of GPS receivers, which boosts the possibilities of its applications to similar works in a crucial way, and also contributes to more frequent monitoring of the selected water bodies.

The precise measurement of the location of the lake's shoreline is now possible regardless of a season. The present condition registered with great accuracy will constitute a reference point for future field explorations. In future it will be possible to conduct investigations with approximate accuracy on the grounds of present photogrammetric flights, where a terrain pixel may reach the size of even $10 \mathrm{~cm}$.

\section{References}

Choiński A., 2001, Analisys of changes in the area and water volume of Lake Jamno, Limnol. Rev. 1: 41-44.

Dorożyński R., Skowron R., 2002, Changes of the basin of Lake Gopło caused by melioration work in the $18^{\text {th }}$ and $19^{\text {th }}$ centuries, Limnol. Rev. 2: 93-102.

Ilnicki P., Orłowski W., 2006, Klęska ekologiczna w Powidzkim Parku Krajobrazowym (Ecological defeat in Powidz Lanscape Park), Aura 10: 11-14 (in Polish).

Ilnicki P.,1996, Wpływ drenażu odkrywek węgla brunatnego na walory rekreacyjne Pojezierza Gnieźnieńskiego (The influence of drainage in Mine of lignite on values the recreational Lake district Gnieźnieńskie), Aura 11: 10-12 (in Polish).
Kaniecki A., 1997, Wpływ XIX-wiecznych melioracji na zmiany poziomu wód (Influence of XIX ${ }^{\text {th }}$ centuries the meliorations on change of level of waters), [in:] A. Choiński (ed.) Wpływ antropopresji na jeziora (Influence of human impact on lake), Wyd. UAM, PoznańBydgoszcz: 67-71 (in Polish).

Marszelewski W., 2005, Zmiany warunków abiotycznych w jeziorach Polski Północno-Wschodniej (Changes of the abiotic condittionsin the lakes of North-East Poland), Wyd. UMK, Toruń, p. 288 (in Polish, English summary).

Marszelewski W., Radomski B., 2008, Quantitative degradation of water resources of the lakes in the eastern part of the Gniezno Lakeland, [in:] E. Bajkiewicz-Grabowska, D. Borowiak (eds), Anthropogenic and natural transformations of lakes, KLUG-PTLim, Gdańsk: 119-122.

Niewiarowski W., 1978, Fluctuations of water-level in the Gopło lake their reasons, Pol. Arch. Hydrobiol. 25: 301306.

Orłowski W., Ilnicki P., 2007, Problemy gospodarowania wodą w otoczeniu Kopalni Węgla Brunatnego Konin (Problems of water management in the surroundings of the Brown Coal Mine Konin), Gosp. Wod. 67(9): 383386 (in Polish).

Pasławski Z., 1968. Zmiany stosunków wodnych w zlewni szczytowego stanowiska kanału żeglugi Warta-Gopło (The change of water relations in catchement of channel the Warta-Gopło), Prz. Geofiz.13 (4): 345-363 (in Polish, English summary).

Sawicki J., Gutry-Korycka M., 1993, Wpływ kopalnictwa (Influence of mining), [in:] I. Dynowska (ed.) Przemiany stosunków wodnych w Polsce w wyniku procesów naturalnych i antropogenicznych (Alteration of water conditions in Poland as a result of natural and anthropogenic processes), Kraków: 354-371 (in Polish).

Skowron R., 2004, Description of lake basin in the light of selected morphometric indicators, Limnol. Rev. 4: 233240.

Wachowiak G., 2005, Rozwój zespołu górniczo-energetycznego „Bełchatów” na tle lokalizacji posterunków wodowskazowych Działu Służby Obserwacyjno-Pomiarowej Oddziału IMGW w Poznaniu (The development of the minig and energy team „Bełchatów” against the location of water level stations of IMGW in Poznań), Gaz. Obserw. IMGW 58(5): 9-13 (in Polish). 